\title{
Stimulation of Eryptosis by Cryptotanshinone
}

\author{
Rosi Bissinger Adrian Lupescu Christine Zelenak Kashif Jilani Florian Lang \\ Department of Physiology, University of Tübingen, Tübingen, Germany
}

\section{Key Words}

Phosphatidylserine $\bullet$ Cryptotanshinone $\bullet$ Calcium $•$ Cell volume $•$ Eryptosis

\begin{abstract}
Background/Aims: Cryptotanshinone, a component of Salvia miltiorrhiza Bunge roots, may trigger suicidal death or apoptosis of tumor cells and has thus been recommended for the prevention and treatment of malignancy. On the other hand, Cryptotanshinone has been shown to counteract apoptosis of neurons and hepatocytes. Similar to apoptosis of nucleated cells, erythrocytes may enter eryptosis, a suicidal death characterized by cell shrinkage and phosphatidylserine translocation to the erythrocyte surface. Eryptosis may be triggered by increase of cytosolic $\mathrm{Ca}^{2+}$-activity $\left(\left[\mathrm{Ca}^{2+}\right]_{\mathrm{i}}\right)$. The present study explored whether Cryptotanshinone stimulates eryptosis. Methods: Forward scatter was taken as measure of cell volume, annexin $\mathrm{V}$ binding for identification of phosphatidylserine-exposing erythrocytes and Fluo3-fluorescence for determination of $\left[\mathrm{Ca}^{2+}\right]_{i}$. Results: A $48 \mathrm{~h}$ exposure of human erythrocytes to Cryptotanshinone $(10 \mu \mathrm{M})$ was followed by significant decrease of forward scatter, significant increase of the percentage annexin-V-binding cells and significant increase of $\left[\mathrm{Ca}^{2+}\right]_{i}$. The effect of Cryptotanshinone $(1 \mu \mathrm{M})$ on annexin-V-binding was virtually abrogated by removal of extracellular $\mathrm{Ca}^{2+}$. Conclusion: Cryptotanshinone is a powerful stimulator of suicidal erythrocyte death or eryptosis, which is effective mainly, if not exclusively, by stimulation of $\mathrm{Ca}^{2+}$ entry.

Copyright $(2014$ S. Karger AG, Basel
\end{abstract}

\section{Introduction}

Cryptotanshinone is a terpenoid isolated from the roots of Salvia miltiorrhiza Bunge, which have been used in traditional Chinese medicine for treatment of a wide variety of clinical conditions [1-4]. Cryptotanshinone has been shown to be particularly effective in the 
prevention and treatment of malignancy [1]. The efficacy of Cryptotanshinone in cancer has been attributed to stimulation of suicidal cell death or apoptosis [5-16]. The proapoptotic effect of Cryptotanshinone has partially been explained by sensitisation to TRAIL $[15,17]$. On the other hand, Cryptotanshinone has been shown to counteract apoptosis in some cell types [18-23].

In analogy to apoptosis of nucleated cells, erythrocytes may enter suicidal death or eryptosis, which is characterized by cell shrinkage and translocation of phosphatidylserine from the cell interior to the cell surface [24]. Stimulators of eryptosis include increase of cytosolic $\mathrm{Ca}^{2+}$ concentration $\left(\left[\mathrm{Ca}^{2+}\right]_{\mathrm{i}}\right)$, which activates $\mathrm{Ca}^{2+}$-sensitive $\mathrm{K}^{+}$channels with subsequent $\mathrm{K}^{+}$exit, hyperpolarization, $\mathrm{Cl}^{-}$exit and thus cellular loss of $\mathrm{KCl}$ and water leading to cell shrinkage [25]. Increased $\left[\mathrm{Ca}^{2+}\right]_{i}$ triggers in addition phospholipid scrambling of the cell membrane with phosphatidylserine exposure at the erythrocyte surface [24]. Further triggers of eryptosis include ceramide formation [26], caspase activation [27-31] and deranged activities of AMP activated kinase AMPK [32], casein kinase $1 \alpha[33,34]$, cGMPdependent protein kinase [35], Janus-activated kinase JAK3 [36], protein kinase C [37], p38 kinase [38], PAK2 kinase [39] sorafenib sensitive kinases [40] as well as sunitinib sensitive kinases [41].

Eryptosis is triggered by a myriad of xenobiotics [26, 40-74] and excessive eryptosis is observed in a wide variety of clinical conditions, such as sepsis, malaria, sickle cell disease, Wilson's disease, iron deficiency, malignancy, metabolic syndrome, diabetes, renal insufficiency, hemolytic uremic syndrome, hyperphosphatemia and phosphate depletion $[24,75]$.

The present study explored, whether Cryptotanshinone stimulates or interferes with eryptosis. To this end, the effect of Cryptotanshinone on $\left[\mathrm{Ca}^{2+}\right]_{i}$, cell volume and phosphatidylserine abundance at the surface of human erythrocytes have been determined utilizing flow cytometry.

\section{Materials and Methods}

Erythrocytes, solutions and chemicals

Leukocyte-depleted erythrocytes were kindly provided by the blood bank of the University of Tübingen. The study is approved by the ethics committee of the University of Tübingen (184/2003V). Erythrocytes were incubated in vitro at a hematocrit of $0.4 \%$ in Ringer solution containing (in mM) $125 \mathrm{NaCl}, 5 \mathrm{KCl}, 1 \mathrm{MgSO}_{4}$, $32 \mathrm{~N}$-2-hydroxyethylpiperazine-N-2-ethanesulfonic acid (HEPES), 5 glucose, $1 \mathrm{CaCl}_{2} ; \mathrm{pH} 7.4$ at $37^{\circ} \mathrm{C}$ for $48 \mathrm{~h}$. Where indicated, erythrocytes were exposed to Cryptotanshinone (Enzo, Lörrach, Germany) at the indicated concentrations. In $\mathrm{Ca}^{2+}$-free Ringer solution, $1 \mathrm{mM} \mathrm{CaCl}_{2}$ was substituted by $1 \mathrm{mM} \mathrm{glycol-bis(2-aminoethylether)-}$ $\mathrm{N}, \mathrm{N}, \mathrm{N}$ ',N'-tetraacetic acid (EGTA).

Analysis of annexin-V-binding and forward scatter

After incubation under the respective experimental condition, $50 \mu \mathrm{l}$ cell suspension was washed in Ringer solution containing $5 \mathrm{mM} \mathrm{CaCl}_{2}$ and then stained with Annexin-V-FITC (1:200 dilution; ImmunoTools, Friesoythe, Germany) in this solution at $37^{\circ} \mathrm{C}$ for 20 min under protection from light. In the following, the forward scatter (FSC) of the cells was determined, and annexin-V fluorescence intensity was measured with an excitation wavelength of $488 \mathrm{~nm}$ and an emission wavelength of $530 \mathrm{~nm}$ on a FACS Calibur (BD, Heidelberg, Germany).

\section{Measurement of intracellular $\mathrm{Ca}^{2+}$}

After incubation, erythrocytes were washed in Ringer solution and then loaded with Fluo-3/AM (Biotium, Hayward, USA) in Ringer solution containing $5 \mathrm{mM} \mathrm{CaCl}_{2}$ and $5 \mu \mathrm{M}$ Fluo-3/AM. The cells were incubated at $37^{\circ} \mathrm{C}$ for $30 \mathrm{~min}$ and washed twice in Ringer solution containing $5 \mathrm{mM} \mathrm{CaCl} 2^{\text {. The Fluo-3/ }}$ AM-loaded erythrocytes were resuspended in $200 \mu \mathrm{l}$ Ringer. Then, $\mathrm{Ca}^{2+}$-dependent fluorescence intensity was measured with an excitation wavelength of $488 \mathrm{~nm}$ and an emission wavelength of $530 \mathrm{~nm}$ on a FACS Calibur. 


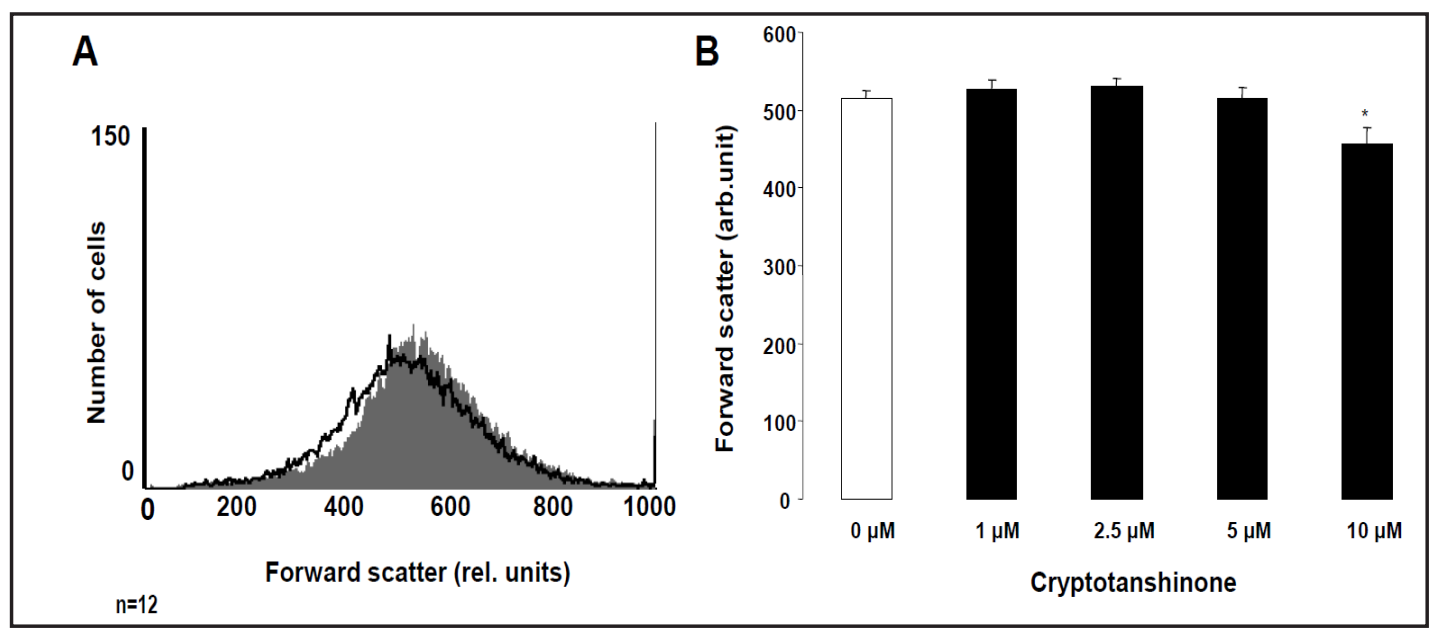

Fig. 1. Effect of Cryptotanshinone on erythrocyte forward scatter. A. Original histogram of forward scatter of erythrocytes following exposure for $48 \mathrm{~h}$ to Ringer solution without (grey area) and with (black line) presence of $10 \mu \mathrm{M}$ Cryptotanshinone. B. Arithmetic means \pm SEM ( $n=8)$ of the normalized erythrocyte forward scatter (FSC) following incubation for $48 \mathrm{~h}$ to Ringer solution without (white bar) or with (black bars) Cryptotanshinone $(1-10 \mu \mathrm{M}) .{ }^{*}(\mathrm{p}<0.05)$ indicates significant difference from the absence of Cryptotanshinone (ANOVA).

\section{Statistics}

Data are expressed as arithmetic means \pm SEM. As indicated in the figure legends, statistical analysis was made using ANOVA with Tukey's test as post-test and $t$ test as appropriate; $\mathrm{n}$ denotes the number of different erythrocyte specimens studied. Since different erythrocyte specimens used in distinct experiments are differently susceptible to triggers of eryptosis, the same erythrocyte specimens have been used for control and experimental conditions.

\section{Results}

The present study explored the influence of the terpenoid Cryptotanshinone on eryptosis, the suicidal erythrocyte death characterized by cell shrinkage and phosphatidylserine translocation to the cell surface.

In order to estimate alterations of cell volume, forward scatter was determined in flow cytometry following incubation of the erythrocytes for $48 \mathrm{~h}$ in Ringer solution without or with Cryptotanshinone (1-10 $\mu \mathrm{M})$. As illustrated in Fig. 1, a $48 \mathrm{~h}$ exposure to Cryptotanshinone was followed by a decrease of forward scatter, an effect reaching statistical significance at 10 $\mu \mathrm{M}$ Cryptotanshinone concentration. Accordingly, Cryptotanshinone treatment was followed by erythrocyte shrinkage.

Cell membrane phospholipid scrambling with phosphatidylserine translocation to the erythrocyte surface was quantified utilizing annexin-V-binding in flow cytometry. The annexin $\mathrm{V}$ binding was determined following incubation of the erythrocytes for $48 \mathrm{~h}$ in Ringer solution without or with Cryptotanshinone (1-10 $\mu \mathrm{M})$. As illustrated in Fig. 2, a 48 $\mathrm{h}$ exposure to Cryptotanshinone was followed by an increase of the percentage annexin-Vbinding erythrocytes, an effect reaching statistical significance at $5 \mu \mathrm{M}$ Cryptotanshinone concentration. Thus, Cryptotanshinone triggered erythrocyte cell membrane scrambling with subsequent translocation of phosphatidylserine to the cell surface.

Since both, cell shrinkage and cell membrane scrambling with phosphatidylserine translocation to the cell surface are stimulated by increase of cytosolic $\mathrm{Ca}^{2+}$ activity $\left(\left[\mathrm{Ca}^{2+}\right]_{\mathrm{i}}\right)$, further experiments estimated the effect of Cryptotanshinone on $\left[\mathrm{Ca}^{2+}\right]_{\mathrm{i}}$. To this end, 


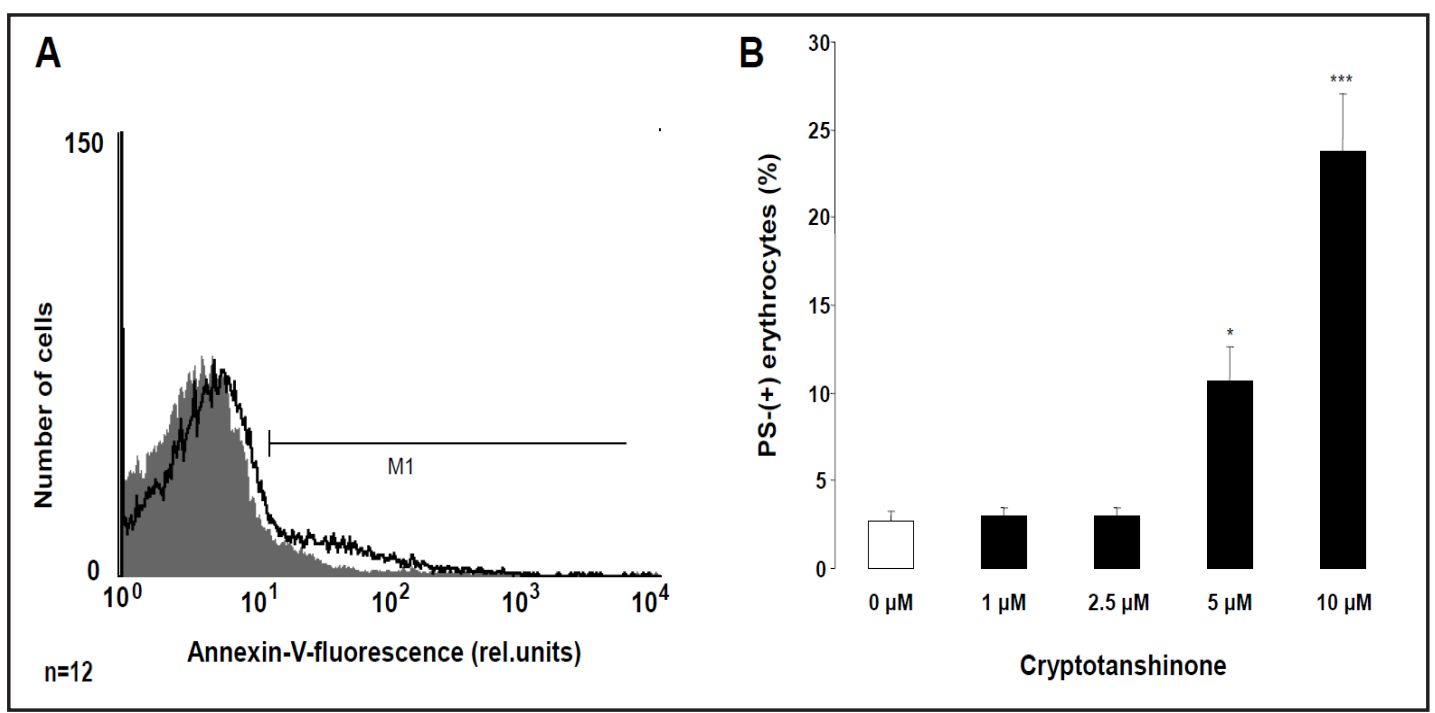

Fig. 2. Effect of Cryptotanshinone on phosphatidylserine exposure. A. Original histogram of annexin-Vbinding of erythrocytes following exposure for $48 \mathrm{~h}$ to Ringer solution without (grey area) and with (black line) presence of $10 \mu \mathrm{M}$ Cryptotanshinone. B. Arithmetic means \pm SEM $(n=8)$ of erythrocyte annexin-Vbinding following incubation for $48 \mathrm{~h}$ to Ringer solution without (white bar) or with (black bars) presence of Cryptotanshinone $(1-10 \mu \mathrm{M}) .{ }^{*}(\mathrm{p}<0.05),{ }^{* *}(\mathrm{p}<0.001)$ indicate significant difference from the absence of Cryptotanshinone (ANOVA).

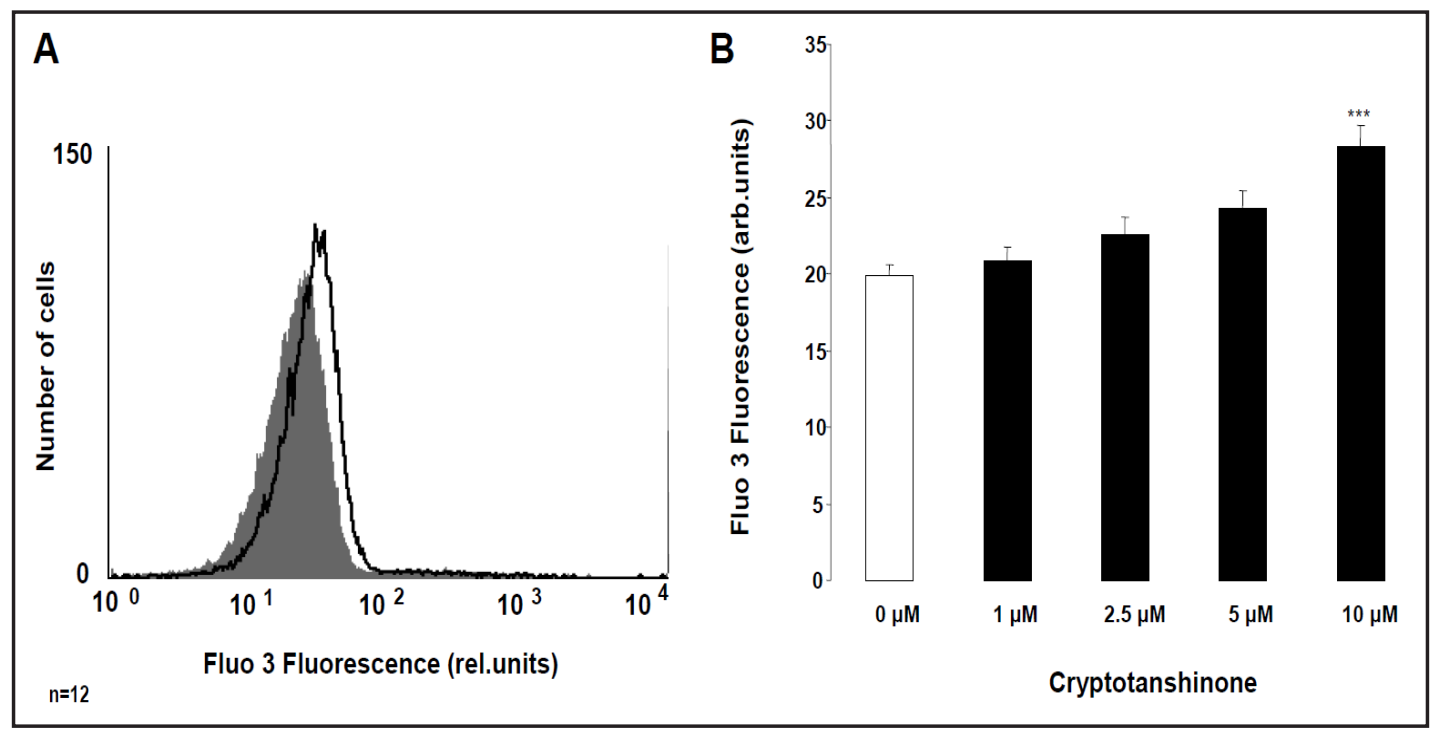

Fig. 3. Effect of Cryptotanshinone on erythrocyte cytosolic $\mathrm{Ca}^{2+}$ concentration. A. Original histogram of Fluo3 fluorescence in erythrocytes following exposure for $48 \mathrm{~h}$ to Ringer solution without (grey area) and with (black line) presence of $10 \mu \mathrm{M}$ Cryptotanshinone. B. Arithmetic means \pm SEM $(n=8)$ of the Fluo3 fluorescence (arbitrary units) in erythrocytes exposed for $48 \mathrm{~h}$ to Ringer solution without (white bar) or with (black bars) Cryptotanshinone $(1-10 \mu \mathrm{M}) .{ }^{* * *}(\mathrm{p}<0.001)$ indicates significant difference from the absence of Cryptotanshinone (ANOVA).

erythrocytes were loaded with Fluo3-AM and the Fluo3 fluorescence determined by flow cytometry. Prior to determination of Fluo3-fluorescence, erythrocytes were incubated for 48 $\mathrm{h}$ in Ringer solution without or with Cryptotanshinone (1-10 $\mu \mathrm{M})$. As shown in Fig. 3, exposure of the erythrocytes to Cryptotanshinone was followed by an increase of Fluo3 fluorescence, an effect reaching statistical significance at $10 \mu \mathrm{M}$ Cryptotanshinone concentration. Thus, Cryptotanshinone increased cytosolic $\mathrm{Ca}^{2+}$ concentration. 
Fig. 4. Effect of $\mathrm{Ca}^{2+}$ withdrawal on Cryptotanshinone- induced annexin-V-binding. Arithmetic means \pm SEM $(n=4)$ of the percentage of annexin-V-binding erythrocytes after a $48 \mathrm{~h}$ treatment with Ringer solution without (white bar) or with (black bars) $10 \mu \mathrm{M}$ Cryptotanshinone in the presence (left bars, Plus Calcium) and absence (right bars, Minus Calcium) of calcium. $* * *(p<0.001)$ indicates significant difference from the respective values in absence of Cryptotanshinone, \#\#\# $(\mathrm{p}<0.001)$ indicates significant difference from the respective value in the presence of $\mathrm{Ca}^{2+}$ (ANOVA).

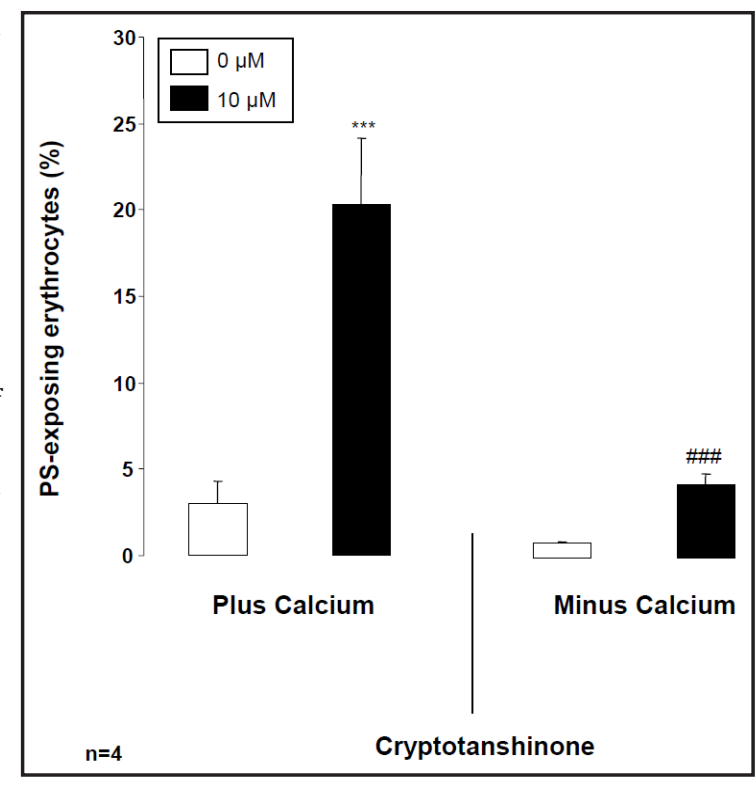

A further series of experiments explored, whether the Cryptotanshinone induced cell membrane scrambling required entry of extracellular $\mathrm{Ca}^{2+}$. To this end, erythrocytes were exposed for $48 \mathrm{~h}$ to $10 \mu \mathrm{M}$ Cryptotanshinone in the presence or nominal absence of extracellular $\mathrm{Ca}^{2+}$. As shown in Fig. 4, the effect of Cryptotanshinone on annexin-V-binding was significantly blunted and virtually abrogated in the nominal absence of $\mathrm{Ca}^{2+}$. In the nominal absence of Cryptotanshinone the percentage of annexin $\mathrm{V}$ binding erythrocytes was not significantly different between presence and absence of Cryptotanshinone. Thus, Cryptotanshinone was effective mainly, if not exclusively, through stimulation of $\mathrm{Ca}^{2+}$ entry.

\section{Discussion}

The present study reveals that Cryptotanshinone stimulates eryptosis, the suicidal death of erythrocytes. Specifically, Cryptotanshinone triggered erythrocyte shrinkage and cell membrane scrambling with phosphatidylserine translocation to the erythrocyte surface. The Cryptotanshinone concentrations $(10 \mu \mathrm{M})$ required for those effects were similar to those determined in Cryptotanshinone treated animals [76].

Cryptotanshinone triggered cell shrinkage presumably by increasing entry of extracellular $\mathrm{Ca}^{2+}$ with subsequent increase of $\left[\mathrm{Ca}^{2+}\right]_{\mathrm{i}^{\prime}}$, activation of $\mathrm{Ca}^{2+}$ sensitive $\mathrm{K}^{+}$channels, $\mathrm{K}^{+}$exit, cell membrane hyperpolarisation, $\mathrm{Cl}^{-}$exit and thus cellular loss of $\mathrm{KCl}$ with osmotically obliged water [25]. Exit of cellular $\mathrm{KCl}$ with water counteracts erythrocyte swelling, which may lead to hemolysis with subsequent release of hemoglobin. The hemoglobin released during hemolysis may be filtered in renal glomeruli and subsequently precipitate in the acidic lumen of renal tubules [77].

Increase of $\left[\mathrm{Ca}^{2+}\right]_{i}$ further largely accounts for the stimulation of cell membrane scrambling by Cryptotanshinone. Apparently, Cryptotanshinone stimulates $\mathrm{Ca}^{2+}$ entry and its effect on cell membrane scrambling requires the presence of extracellular $\mathrm{Ca}^{2+}$.

The ability of cryptotanshinone to trigger eryptosis is similar to that of tanshinone II [61]. Both, Cryptotanshinone [1] and Tanshinone [78] are utilized in the prevention and treatment of malignancy. Tanshinone [79-81] and Cryptotanshinone [2, 3] further exert several beneficial cardiovascular effects. Salvia plants have anti-oxidant, antimicrobial, antiplasmodial, analgesic, antipyretic, anticancer, anti-inflammatory and antinociceptive activities [82].

Stimulation of eryptosis fosters elimination of defective erythrocytes and may thus protect against untoward effects of hemolysis [24]. The removal of phosphatidylserine 
exposing erythrocytes is particularly important during the course of malaria [83]. The intraerythrocytic parasite triggers eryptosis of infected erythrocytes [83] by activation of ion channels including the $\mathrm{Ca}^{2+}$-permeable erythrocyte cation channels $[84,85]$. The channel activity is required for the intraerythrocytic survival of the pathogen [84, 85], as the channels mediate entry of nutrients, $\mathrm{Na}^{+}$and $\mathrm{Ca}^{2+}$ as well as disposal of intracellular waste products [85]. $\mathrm{Ca}^{2+}$ entry through the $\mathrm{Ca}^{2+}$-permeable cation channels triggers, however, eryptosis leading to rapid clearance of the infected erythrocytes from circulating blood [83]. Thus, eryptosis counteracts parasitemia by triggering elimination of the infected erythrocyte and thus of the pathogen [83]. Along those lines, genetic disorders sensitizing erythrocytes to eryptosis, such as sickle-cell trait, beta-thalassemia-trait, homozygous $\mathrm{Hb}-\mathrm{C}$ and G6PDdeficiency $[24,86]$ are associated with a relatively mild clinical course of malaria $[24,87-$ 89]. Moreover, clinical conditions with enhanced eryptosis, such as iron deficiency [90-95], and eryptosis stimulating drugs, such as lead [96], chlorpromazine [97] or NO synthase inhibitors [98] favourably influence the clinical course of malaria. Thus, at least in theory, Cryptotanshinone may similarly decrease parasitemia in malaria. Notably, Salvia is used for the treatment of malaria [82]. The efficacy may, however, at least in part be due to a more direct toxic effect on plasmodia [82].

Excessive stimulation of eryptosis may, however, result in anemia. Phagocytosis of phosphatidylserine exposing eryptotic erythrocytes leads to rapid removal of those cells and thus to a decrease of erythrocytes in circulating blood [24]. To the extent that the accelerated clearance of erythrocytes during stimulated eryptosis cannot be compensated by a similarly accelerated formation of new erythrocytes, anemia develops [24]. Phosphatidylserine exposing erythrocytes further adhere to endothelial CXCL16/SR-PSO [99] and stimulate blood clotting and thrombosis [100-102]. Thus, excessive eryptosis does interfere with microcirculation [99, 100, 103-106]. The effect of Cryptotanshinone on anemia and microcirculation may be augmented by other xenobiotics triggering eryptosis or in clinical disorders associated with enhanced eryptosis, such as renal insufficiency, diabetes or sepsis (see introduction).

\section{Conclusion}

The exposure of human erythrocytes to Cryptotanshinone stimulates $\mathrm{Ca}^{2+}$ entry, erythrocyte shrinkage and erythrocyte cell membrane scrambling. Thus, Cryptotanshinone triggers eryptosis, the suicidal erythrocyte death.

\section{Disclosure Statement}

The authors of this manuscript state that they do not have any conflict of interests and nothing to disclose.

\section{Acknowledgements}

The authors acknowledge the meticulous preparation of the manuscript by Tanja Loch. The study was supported by the Deutsche Forschungsgemeinschaft and Open Access Publishing Fund of Tuebingen University.

\section{References}

\footnotetext{
1 Chen W, Lu Y, Chen G, Huang S: Molecular evidence of cryptotanshinone for treatment and prevention of human cancer. Anticancer Agents Med Chem 2013;13:979-987.

2 Han JY, Fan JY, Horie Y, Miura S, Cui DH, Ishii H, Hibi T, Tsuneki H, Kimura I: Ameliorating effects of compounds derived from Salvia miltiorrhiza root extract on microcirculatory disturbance and target organ injury by ischemia and reperfusion. Pharmacol Ther 2008;117:280-295.
} 
3 Tian XH, Wu JH: Tanshinone derivatives: a patent review (January 2006 - September 2012). Expert Opin Ther Pat 2013;23:19-29.

4 Yoo KY, Park SY: Terpenoids as potential anti-Alzheimer's disease therapeutics. Molecules 2012;17:35243538.

5 Ge Y, Cheng R, Zhou Y, Shen J, Peng L, Xu X, Dai Q Liu P, Wang H, Ma X, Jia J, Chen Z: Cryptotanshinone induces cell cycle arrest and apoptosis of multidrug resistant human chronic myeloid leukemia cells by inhibiting the activity of eukaryotic initiation factor 4E. Mol Cell Biochem 2012;368:17-25.

6 Gong Y, Li Y, Lu Y, Li L, Abdolmaleky H, Blackburn GL, Zhou JR: Bioactive tanshinones in Salvia miltiorrhiza inhibit the growth of prostate cancer cells in vitro and in mice. Int J Cancer 2011;129:1042-1052.

7 Jung JH, Kwon TR, Jeong SJ, Kim EO, Sohn EJ, Yun M, Kim SH: Apoptosis Induced by Tanshinone IIA and Cryptotanshinone Is Mediated by Distinct JAK/STAT3/5 and SHP1/2 Signaling in Chronic Myeloid Leukemia K562 Cells. Evid Based Complement Alternat Med 2013;2013:805639.

8 Kim JH, Jeong SJ, Kwon TR, Yun SM, Jung JH, Kim M, Lee HJ, Lee MH, Ko SG, Chen CY, Kim SH: Cryptotanshinone enhances TNF-alpha-induced apoptosis in chronic myeloid leukemia KBM-5 cells. Apoptosis 2011;16:696-707.

-9 Lee WY, Liu KW, Yeung JH: Reactive oxygen species-mediated kinase activation by dihydrotanshinone in tanshinones-induced apoptosis in HepG2 cells. Cancer Lett 2009;285:46-57.

10 Li H, Zhang Q Chu T, Shi HY, Fu HM, Song XR, Meng WT, Mao SJ, Jia YQ: Growth-inhibitory and apoptosisinducing effects of tanshinones on hematological malignancy cells and their structure-activity relationship. Anticancer Drugs 2012;23:846-855.

11 Li Y, Gong Y, Li L, Abdolmaleky HM, Zhou JR: Bioactive tanshinone I inhibits the growth of lung cancer in part via downregulation of Aurora A function. Mol Carcinog 2013;52:535-543.

12 Liu P, Xu S, Zhang M, Wang WW, Zhang YF, Rehman K, Naranmandura H, Chen Z: Anticancer activity in human multiple myeloma U266 cells: synergy between cryptotanshinone and arsenic trioxide. Metallomics 2013;5:871-878.

13 Park IJ, Kim MJ, Park OJ, Choe W, Kang I, Kim SS, Ha J: Cryptotanshinone induces ER stress-mediated apoptosis in HepG2 and MCF7 cells. Apoptosis 2012;17:248-257.

14 Park IJ, Kim MJ, Park OJ, Park MG, Choe W, Kang I, Kim SS, Ha J: Cryptotanshinone sensitizes DU145 prostate cancer cells to Fas(AP01/CD95)-mediated apoptosis through Bcl-2 and MAPK regulation. Cancer Lett 2010;298:88-98.

15 Tse AK, Chow KY, Cao HH, Cheng CY, Kwan HY, Yu H, Zhu GY, Wu YC, Fong WF, Yu ZL: The herbal compound cryptotanshinone restores sensitivity in cancer cells that are resistant to the tumor necrosis factor-related apoptosis-inducing ligand. J Biol Chem 2013;288:29923-29933.

-16 Park IJ, Yang WK, Nam SH, Hong J, Yang KR, Kim J, Kim SS, Choe W, Kang I, Ha J: Cryptotanshinone induces G1 cell cycle arrest and autophagic cell death by activating the AMP-activated protein kinase signal pathway in HepG2 hepatoma. Apoptosis 2014;19:615-628.

17 Chang CC, Lai JS, Tsai CS, Ma SW, Lin JY, Huang LR, Lu CH, Liao EC, Ho TF: Proapoptotic and TRAILsensitizing constituents isolated from Salvia militiorrhiza (Danshen). J Biosci Bioeng 2013;116:516-523.

-18 Jin HJ, Xie XL, Ye JM, Li CG: TanshinoneIIA and cryptotanshinone protect against hypoxia-induced mitochondrial apoptosis in H9c2 cells. PLoS One 2013;8:e51720.

19 Jin Q, Jiang S, Wu YL, Bai T, Yang Y, Jin X, Lian LH, Nan JX: Hepatoprotective effect of cryptotanshinone from Salvia miltiorrhiza in d-galactosamine/lipopolysaccharide-induced fulminant hepatic failure. Phytomedicine 2014;21:141-147.

20 Mahesh R, Jung HW, Kim GW, Kim YS, Park YK: Cryptotanshinone from Salviae miltiorrhizae radix inhibits sodium-nitroprusside-induced apoptosis in neuro-2a cells. Phytother Res 2012;26:1211-1219.

-21 Mei Z, Yan P, Situ B, Mou Y, Liu P: Cryptotanshinione inhibits beta-amyloid aggregation and protects damage from beta-amyloid in SH-SY5Y cells. Neurochem Res 2012;37:622-628.

-22 Park EJ, Zhao YZ, Kim YC, Sohn DH: PF2401-SF, standardized fraction of Salvia miltiorrhiza and its constituents, tanshinone I, tanshinone IIA, and cryptotanshinone, protect primary cultured rat hepatocytes from bile acid-induced apoptosis by inhibiting JNK phosphorylation. Food Chem Toxicol 2007;45:18911898.

23 Zhang F, Zheng W, Pi R, Mei Z, Bao Y, Gao J, Tang W, Chen S, Liu P: Cryptotanshinone protects primary rat cortical neurons from glutamate-induced neurotoxicity via the activation of the phosphatidylinositol 3-kinase/Akt signaling pathway. Exp Brain Res 2009;193:109-118. 
24 Lang E, Qadri SM, Lang F: Killing me softly - suicidal erythrocyte death. Int J Biochem Cell Biol 2012;44:1236-1243.

25 Lang PA, Kaiser S, Myssina S, Wieder T, Lang F, Huber SM: Role of Ca2+-activated K+ channels in human erythrocyte apoptosis. Am J Physiol Cell Physiol 2003;285:C1553-C1560.

26 Abed M, Towhid ST, Mia S, Pakladok T, Alesutan I, Borst O, Gawaz M, Gulbins E, Lang F: Sphingomyelinaseinduced adhesion of eryptotic erythrocytes to endothelial cells. Am J Physiol Cell Physiol 2012;303:C991999.

-27 Bhavsar SK, Bobbala D, Xuan NT, Foller M, Lang F: Stimulation of suicidal erythrocyte death by alpha-lipoic acid. Cell Physiol Biochem 2010;26:859-868.

-28 Foller M, Huber SM, Lang F: Erythrocyte programmed cell death. IUBMB Life 2008;60:661-668.

-29 Foller M, Mahmud H, Gu S, Wang K, Floride E, Kucherenko Y, Luik S, Laufer S, Lang F: Participation of leukotriene C(4) in the regulation of suicidal erythrocyte death. J Physiol Pharmacol 2009;60:135-143.

-30 Lau IP, Chen H, Wang J, Ong HC, Leung KC, Ho HP, Kong SK: In vitro effect of CTAB- and PEG-coated gold nanorods on the induction of eryptosis/erythroptosis in human erythrocytes. Nanotoxicology 2012;6:847856.

31 Maellaro E, Leoncini S, Moretti D, Del Bello B, Tanganelli I, De Felice C, Ciccoli L: Erythrocyte caspase-3 activation and oxidative imbalance in erythrocytes and in plasma of type 2 diabetic patients. Acta Diabetol 2013;50:489-495.

-32 Foller M, Sopjani M, Koka S, Gu S, Mahmud H, Wang K, Floride E, Schleicher E, Schulz E, Munzel T, Lang F: Regulation of erythrocyte survival by AMP-activated protein kinase. FASEB J 2009;23:1072-1080.

-33 Kucherenko Y, Zelenak C, Eberhard M, Qadri SM, Lang F: Effect of casein kinase 1alpha activator pyrvinium pamoate on erythrocyte ion channels. Cell Physiol Biochem 2012;30:407-417.

-34 Zelenak C, Eberhard M, Jilani K, Qadri SM, Macek B, Lang F: Protein kinase CK1alpha regulates erythrocyte survival. Cell Physiol Biochem 2012;29:171-180.

-35 Foller M, Feil S, Ghoreschi K, Koka S, Gerling A, Thunemann M, Hofmann F, Schuler B, Vogel J, Pichler B, Kasinathan RS, Nicolay JP, Huber SM, Lang F, Feil R: Anemia and splenomegaly in cGKI-deficient mice. Proc Natl Acad Sci USA 2008;105:6771-6776.

-36 Bhavsar SK, Gu S, Bobbala D, Lang F: Janus kinase 3 is expressed in erythrocytes, phosphorylated upon energy depletion and involved in the regulation of suicidal erythrocyte death. Cell Physiol Biochem 2011;27:547-556.

37 Klarl BA, Lang PA, Kempe DS, Niemoeller OM, Akel A, Sobiesiak M, Eisele K, Podolski M, Huber SM, Wieder T, Lang F: Protein kinase C mediates erythrocyte "programmed cell death" following glucose depletion. Am J Physiol Cell Physiol 2006;290:C244-C253.

-38 Gatidis S, Zelenak C, Fajol A, Lang E, Jilani K, Michael D, Qadri SM, Lang F: p38 MAPK activation and function following osmotic shock of erythrocytes. Cell Physiol Biochem 2011;28:1279-1286.

-39 Zelenak C, Foller M, Velic A, Krug K, Qadri SM, Viollet B, Lang F, Macek B: Proteome analysis of erythrocytes lacking AMP-activated protein kinase reveals a role of PAK2 kinase in eryptosis. J Proteome Res 2011;10:1690-1697.

-40 Lupescu A, Jilani K, Zelenak C, Zbidah M, Qadri SM, Lang F: Hexavalent chromium-induced erythrocyte membrane phospholipid asymmetry. Biometals 2012;25:309-318.

41 Shaik N, Lupescu A, Lang F: Sunitinib-sensitive suicidal erythrocyte death. Cell Physiol Biochem 2012;30:512-522.

42 Abed M, Towhid ST, Shaik N, Lang F: Stimulation of suicidal death of erythrocytes by rifampicin. Toxicology 2012;302:123-128.

43 Bottger E, Multhoff G, Kun JF, Esen M: Plasmodium falciparum-infected erythrocytes induce granzyme B by NK cells through expression of host-Hsp70. PLoS One 2012;7:e33774.

44 Firat U, Kaya S, Cim A, Buyukbayram H, Gokalp O, Dal MS, Tamer MN: Increased caspase-3 immunoreactivity of erythrocytes in STZ diabetic rats. Exp Diabetes Res 2012;2012:316384.

45 Ganesan S, Chaurasiya ND, Sahu R, Walker LA, Tekwani BL: Understanding the mechanisms for metabolism-linked hemolytic toxicity of primaquine against glucose 6-phosphate dehydrogenase deficient human erythrocytes: evaluation of eryptotic pathway. Toxicology 2012;294:54-60.

46 Gao M, Cheung KL, Lau IP, Yu WS, Fung KP, Yu B, Loo JF, Kong SK: Polyphyllin D induces apoptosis in human erythrocytes through $\mathrm{Ca}(2)(+)$ rise and membrane permeabilization. Arch Toxicol 2012;86:741-752. 
Bissinger et al: Cryptotanshinone-Induced Eryptosis

47 Ghashghaeinia M, Cluitmans JC, Akel A, Dreischer P, Toulany M, Koberle M, Skabytska Y, Saki M, Biedermann T, Duszenko M, Lang F, Wieder T, Bosman GJ: The impact of erythrocyte age on eryptosis. Br J Haematol 2012;157:606-614.

48 Jilani K, Lupescu A, Zbidah M, Abed M, Shaik N, Lang F: Enhanced Apoptotic Death of Erythrocytes Induced by the Mycotoxin Ochratoxin A. Kidney Blood Press Res 2012;36:107-118.

49 Jilani K, Lupescu A, Zbidah M, Shaik N, Lang F: Withaferin A-stimulated Ca2+ entry, ceramide formation and suicidal death of erythrocytes. Toxicol In Vitro 2013;27:52-58.

-50 Kucherenko YV, Lang F: Inhibitory Effect of Furosemide on Non-Selective Voltage-Independent Cation Channels in Human Erythrocytes. Cell Physiol Biochem 2012;30:863-875.

51 Lupescu A, Jilani K, Zbidah M, Lang E, Lang F: Enhanced ca(2+) entry, ceramide formation, and apoptotic death of erythrocytes triggered by plumbagin. J Nat Prod 2012;75:1956-1961.

52 Lupescu A, Jilani K, Zbidah M, Lang F: Induction of apoptotic erythrocyte death by rotenone. Toxicology 2012;300:132-137.

53 Polak-Jonkisz D, Purzyc L: Ca Influx versus Efflux during Eryptosis in Uremic Erythrocytes. Blood Purif 2012;34:209-210.

54 Qian EW, Ge DT, Kong SK: Salidroside protects human erythrocytes against hydrogen peroxide-induced apoptosis. J Nat Prod 2012;75:531-537.

55 Shaik N, Zbidah M, Lang F: Inhibition of $\mathrm{Ca}(2+)$ entry and suicidal erythrocyte death by naringin. Cell Physiol Biochem 2012;30:678-686.

56 Vota DM, Maltaneri RE, Wenker SD, Nesse AB, Vittori DC: Differential erythropoietin action upon cells induced to eryptosis by different agents. Cell Biochem Biophys 2013;65:145-157.

57 Weiss E, Cytlak UM, Rees DC, Osei A, Gibson JS: Deoxygenation-induced and Ca(2+) dependent phosphatidylserine externalisation in red blood cells from normal individuals and sickle cell patients. Cell Calcium 2012;51:51-56.

58 Zappulla D: Environmental stress, erythrocyte dysfunctions, inflammation, and the metabolic syndrome: adaptations to CO2 increases? J Cardiometab Syndr 2008;3:30-34.

59 Zbidah M, Lupescu A, Jilani K, Lang F: Stimulation of suicidal erythrocyte death by fumagillin. Basic Clin Pharmacol Toxicol 2013;112:346-351.

60 Zbidah M, Lupescu A, Shaik N, Lang F: Gossypol-induced suicidal erythrocyte death. Toxicology 2012;302:101-105.

61 Zelenak C, Pasham V, Jilani K, Tripodi PM, Rosaclerio L, Pathare G, Lupescu A, Faggio C, Qadri SM, Lang F: Tanshinone IIA stimulates erythrocyte phosphatidylserine exposure. Cell Physiol Biochem 2012;30:282294.

62 Abed M, Herrmann T, Alzoubi K, Pakladok T, Lang F: Tannic Acid induced suicidal erythrocyte death. Cell Physiol Biochem 2013;32:1106-1116.

63 Ahmed MS, Langer H, Abed M, Voelkl J, Lang F: The uremic toxin acrolein promotes suicidal erythrocyte death. Kidney Blood Press Res 2013;37:158-167.

64 Ghashghaeinia M, Cluitmans JC, Toulany M, Saki M, Koberle M, Lang E, Dreischer P, Biedermann T, Duszenko M, Lang F, Bosman GJ, Wieder T: Age Sensitivity of NFkappaB Abundance and Programmed Cell Death in Erythrocytes Induced by NFkappaB Inhibitors. Cell Physiol Biochem 2013;32:801-813.

65 Abed M, Feger M, Alzoubi K, Pakladok T, Frauenfeld L, Geiger C, Towhid ST, Lang F: Sensitization of erythrocytes to suicidal erythrocyte death following water deprivation. Kidney Blood Press Res 2013;37:567-578.

66 Alzoubi K, Honisch S, Abed M, Lang F: Triggering of Suicidal Erythrocyte Death by Penta-O-galloyl-beta-dglucose. Toxins (Basel) 2014;6:54-65.

67 Jilani K, Qadri SM, Lang F: Geldanamycin-induced phosphatidylserine translocation in the erythrocyte membrane. Cell Physiol Biochem 2013;32:1600-1609.

68 Jilani K, Lang F: Carmustine-induced phosphatidylserine translocation in the erythrocyte membrane. Toxins (Basel) 2013;5:703-716.

69 Jilani K, Enkel S, Bissinger R, Almilaji A, Abed M, Lang F: Fluoxetine induced suicidal erythrocyte death. Toxins (Basel) 2013;5:1230-1243.

70 Bissinger R, Modicano P, Frauenfeld L, Lang E, Jacobi J, Faggio C, Lang F: Estramustine-induced suicidal erythrocyte death. Cell Physiol Biochem 2013;32:1426-1436. 
Bissinger et al: Cryptotanshinone-Induced Eryptosis

71 Lupescu A, Jilani K, Zbidah M, Lang F: Patulin-induced suicidal erythrocyte death. Cell Physiol Biochem 2013;32:291-299.

72 Lupescu A, Bissinger R, Jilani K, Lang F: Triggering of suicidal erythrocyte death by celecoxib. Toxins (Basel) 2013;5:1543-1554.

73 Lang E, Modicano P, Arnold M, Bissinger R, Faggio C, Abed M, Lang F: Effect of thioridazine on erythrocytes. Toxins (Basel) 2013;5:1918-1931.

74 Lang E, Qadri SM, Jilani K, Zelenak C, Lupescu A, Schleicher E, Lang F: Carbon monoxide-sensitive apoptotic death of erythrocytes. Basic Clin Pharmacol Toxicol 2012;111:348-355.

75 Voelkl J, Alzoubi K, Mamar AK, Ahmed MS, Abed M, Lang F: Stimulation of Suicidal Erythrocyte Death by Increased Extracellular Phosphate Concentrations. Kidney Blood Press Res 2013;38:42-51.

76 Cui Y, Xue M, Luo Y-J, Zhang B, Zhou Z-T: Pharmacokinetics and excretion of cryptotanshinone after intravenous injection in pigs. Asian J Drug Metabol Pharmacokinetics 2005;5:231-235.

77 Harrison HE, Bunting H, Ordway NK, Albrink WS: The Pathogenesis of the Renal Injury Produced in the Dog by Hemoglobin or Methemoglobin. J Exp Med 1947;86:339-356.

78 Zhang Z, Zhang J, Jin L, Song T, Wu G, Gao J: Tanshinone IIA interacts with DNA by minor groove-binding. Biol Pharm Bull 2008;31:2342-2345.

79 Liu JQ, Lee TF, Miedzyblocki M, Chan GC, Bigam DL, Cheung PY: Effects of tanshinone IIA, a major component of Salvia miltiorrhiza, on platelet aggregation in healthy newborn piglets. J Ethnopharmacol 2011;137:44-49.

80 Pan C, Lou L, Huo Y, Singh G, Chen M, Zhang D, Wu A, Zhao M, Wang S, Li J: Salvianolic acid B and tanshinone IIA attenuate myocardial ischemia injury in mice by NO production through multiple pathways. Ther Adv Cardiovasc Dis 2011;5:99-111.

81 Zhang Y, Zhang L, Chu W, Wang B, Zhang J, Zhao M, Li X, Li B, Lu Y, Yang B, Shan H: Tanshinone IIA inhibits miR-1 expression through p38 MAPK signal pathway in post-infarction rat cardiomyocytes. Cell Physiol Biochem 2010;26:991-998.

82 Kamatou GP, Makunga NP, Ramogola WP, Viljoen AM: South African Salvia species: a review of biological activities and phytochemistry. J Ethnopharmacol 2008;119:664-672.

-83 Foller M, Bobbala D, Koka S, Huber SM, Gulbins E, Lang F: Suicide for survival--death of infected erythrocytes as a host mechanism to survive malaria. Cell Physiol Biochem 2009;24:133-140.

84 Duranton C, Huber S, Tanneur V, Lang K, Brand V, Sandu C, Lang F: Electrophysiological properties of the Plasmodium Falciparum-induced cation conductance of human erythrocytes. Cell Physiol Biochem 2003;13:189-198.

85 Kirk K: Membrane transport in the malaria-infected erythrocyte. Physiol Rev 2001;81:495-537.

-86 Taylor SM, Fairhurst RM: Malaria parasites and red cell variants: when a house is not a home. Curr Opin Hematol 2014;21:193-200.

-87 Ayi K, Giribaldi G, Skorokhod A, Schwarzer E, Prendergast PT, Arese P: 16alpha-bromoepiandrosterone, an antimalarial analogue of the hormone dehydroepiandrosterone, enhances phagocytosis of ring stage parasitized erythrocytes: a novel mechanism for antimalarial activity. Antimicrob Agents Chemother 2002;46:3180-3184.

-88 Ayi K, Turrini F, Piga A, Arese P: Enhanced phagocytosis of ring-parasitized mutant erythrocytes: a common mechanism that may explain protection against falciparum malaria in sickle trait and beta-thalassemia trait. Blood 2004;104:3364-3371.

89 Cappadoro M, Giribaldi G, O’Brien E, Turrini F, Mannu F, Ulliers D, Simula G, Luzzatto L, Arese P: Early phagocytosis of glucose-6-phosphate dehydrogenase (G6PD)-deficient erythrocytes parasitized by Plasmodium falciparum may explain malaria protection in G6PD deficiency. Blood 1998;92:2527-2534.

$\$ 90$ Koka S, Foller M, Lamprecht G, Boini KM, Lang C, Huber SM, Lang F: Iron deficiency influences the course of malaria in Plasmodium berghei infected mice. Biochem Biophys Res Commun 2007;357:608-614.

91 Clark MA, Goheen MM, Cerami C: Influence of host iron status on Plasmodium falciparum infection. Front Pharmacol 2014;5:84.

-92 Lang F, Abed M, Lang E, Foller M: Oxidative stress and suicidal erythrocyte death. Antioxid Redox Signal 2014;21:138-153.

93 Sangare L, van Eijk AM, Ter Kuile FO, Walson J, Stergachis A: The association between malaria and iron status or supplementation in pregnancy: a systematic review and meta-analysis. PLoS One 2014;9:e87743. 
94 Schumann K, Solomons NW: Can iron supplementation be reconciled with benefits and risks in areas hyperendemic for malaria? Food Nutr Bull 2013;34:349-356.

$\$ 95$ Spottiswoode N, Duffy PE, Drakesmith H: Iron, anemia and hepcidin in malaria. Front Pharmacol 2014;5:125.

-96 Koka S, Huber SM, Boini KM, Lang C, Foller M, Lang F: Lead decreases parasitemia and enhances survival of Plasmodium berghei-infected mice. Biochem Biophys Res Commun 2007;363:484-489.

-97 Koka S, Lang C, Boini KM, Bobbala D, Huber SM, Lang F: Influence of chlorpromazine on eryptosis, parasitemia and survival of Plasmodium berghe infected mice. Cell Physiol Biochem 2008;22:261-268.

-98 Koka S, Lang C, Niemoeller OM, Boini KM, Nicolay JP, Huber SM, Lang F: Influence of NO synthase inhibitor L-NAME on parasitemia and survival of Plasmodium berghei infected mice. Cell Physiol Biochem 2008;21:481-488.

\$9 Borst O, Abed M, Alesutan I, Towhid ST, Qadri SM, Foller M, Gawaz M, Lang F: Dynamic adhesion of eryptotic erythrocytes to endothelial cells via CXCL16/SR-PSOX. Am J Physiol Cell Physiol 2012;302:C644-C651.

100 Andrews DA, Low PS: Role of red blood cells in thrombosis. Curr Opin Hematol 1999;6:76-82.

101 Chung SM, Bae ON, Lim KM, Noh JY, Lee MY, Jung YS, Chung JH: Lysophosphatidic acid induces thrombogenic activity through phosphatidylserine exposure and procoagulant microvesicle generation in human erythrocytes. Arterioscler Thromb Vasc Biol 2007;27:414-421.

102 Zwaal RF, Comfurius P, Bevers EM: Surface exposure of phosphatidylserine in pathological cells. Cell Mol Life Sci 2005;62:971-988.

103 Closse C, Dachary-Prigent J, Boisseau MR: Phosphatidylserine-related adhesion of human erythrocytes to vascular endothelium. Br J Haematol 1999;107:300-302.

104 Gallagher PG, Chang SH, Rettig MP, Neely JE, Hillery CA, Smith BD, Low PS: Altered erythrocyte endothelial adherence and membrane phospholipid asymmetry in hereditary hydrocytosis. Blood 2003;101:46254627.

105 Pandolfi A, Di Pietro N, Sirolli V, Giardinelli A, Di Silvestre S, Amoroso L, Di Tomo P, Capani F, Consoli A, Bonomini M: Mechanisms of uremic erythrocyte-induced adhesion of human monocytes to cultured endothelial cells. J Cell Physiol 2007;213:699-709.

106 Wood BL, Gibson DF, Tait JF: Increased erythrocyte phosphatidylserine exposure in sickle cell disease: flowcytometric measurement and clinical associations. Blood 1996;88:1873-1880. 